\title{
POLA KOMUNIKASI ORGANISASI PDI PERJUANGAN DALAM PROSES KADERISASI DI DPC KABUPATEN SIDOARJO
}

\author{
Ni Kadek Defvin Setyawati ${ }^{1^{*}}$, Gatut Prijowidodo ${ }^{2}$, Inri Inggrit ${ }^{3}$ \\ ${ }^{1,2,3}$ Program Studi Ilmu Komunikasi, Fakultas Ilmu Komunikasi, Universitas Kristen Petra Surabaya \\ Jl. Siwalankerto 121 - 131, Surabaya 60236, INDONESIA \\ e-mail: kadekdefvin@gmail.com
}

\begin{abstract}
ABSTRAK
Kaderisasi merupakan kewajiban bagi setiap partai. DPC PDI Perjuangan Kabupaten Sidoarjo menjalankan kaderisasinya tidak hanya pada kegiatan formal namun juga pada kegiatan informal yang membuat proses kaderisasinya semakin efektif dibandingkan dengan DPC lainnya. Melihat keefektivitasan kaderisasi tersebut maka penelitian ini dilakukan untuk mengetahui bagaimana pola komunikasi organisasi yang terjadi selama proses kaderisasi. Penelitian dilakukan dengan metode fenomenologi kualitatif. Data diperoleh melalui dokumen dan wawancara mendalam dengan tiga informan. Hasil penelitian menunjukkan DPC Kabupaten Sidoarjo melakukan tiga pola komunikasi organisasi yaitu, pola komunikasi formal, pola komunikasi informal dan pola komunikasi socialization mechanism. Penelitian ini juga menemukan hambatan yang ada dalam proses kaderisasi yaitu, kurangnya sarana dan prasarana yang diperlukan dalam komunikasi untuk mengatasi rentang usia yang jauh; penguasaan teknik dan metode komunikasi yang tidak sesuai, sehingga beberapa pengurus dan kader tidak menguasai media yang digunakan; kondisi fisik kader yang sudah berusia lanjut tidak memungkinkan untuk menerima informasi secara sempurna.
\end{abstract}

Kata kunci: Pola Komunikasi Organisasi, Hambatan Komunikasi, Kaderisasi Politik, Partai Politik, Fenomenologi.

\begin{abstract}
Cadreization is an obligation for each party. DPC PDI Perjuangan Sidoarjo Regency runs its cadre not only in formal activities but also in informal activities that make the process of regeneration more effective compared to other DPC. This study was conducted to find out how the communication patterns that occur during the regeneration process. The research was conducted by qualitative phenomenology method. Data was collected by documents and interviews with three informants. The results showed that the DPC of Sidoarjo Regency did three organizational communication patterns: formal communication patterns, informal communication patterns and communication patterns of socialization mechanism. This study also found the barrier during the regeneration process, that was: the facilities and infrastructure needed in communication for maintaning age range was low; inappropriate communication techniques and methods, the physical condition of existing cadres does not allow to receive information perfectly.
\end{abstract}

Keywords: Communication Pattern, Barrier in Communication, Party Regeneration, Political Parties, Phenomenology.

\section{PENDAHULUAN}

Kehidupan bermasyarakat tidak dapat dilepaskan dari kebutuhan akan pemimpin yang berperan untuk mengatur, dan mengelola sebuah organisasi/ kelompok untuk mencapai tujuan bersama. PDI Perjuangan merupakan salah satu organisasi partai politik yang memiliki kekuasaan cukup besar di Indonesia. Banyaknya jumlah perolehan kursi pada pemilihan umum menunjukkan bahwa para kader PDI Perjuangan mampu menembus saingan-saingan dari kader partai lain untuk berada di tingkat legislatif. Pada pemilihan umum tahun 2014 PDI Perjuangan menduduki peringkat pertama dengan perolehan sebanyak 109 kursi di tingkat DPR RI, atau $18.95 \%$ dari total suara. Di wilayah Provinsi Jawa Timur, pemilihan umum 2014 PDI Perjuangan menempati urutan kedua terbanyak di DPRD Provinsi Jawa
Timur yaitu dengan perolehan suara $18,92 \%$. Wilayah Kabupaten Sidoarjo, pada pemilihan umum 2014 berhasil memperoleh 97,102 suara di DPRD, hal ini menjadikan PDI Perjuangan menempati urutan kedua terbanyak di wilayah Kabupaten Sidoarjo.

PDI Perjuangan Jawa Timur dalam struktur kepengurusan terbagi ke dalam beberapa wilayah kordinasi yang mengacu pada bekas keresidenan. Sidoarjo tercakup dalam lingkup Gerbangkertasusila, yang juga meliputi wilayah Gresik, Bangkalan, Mojokerto, Surabaya, dan Lamongan. Berdasarkan wawancara pra-penelitian yang dilakukan di Kantor DPD PDI Perjuangan Provinsi Jawa Timur, Kabupaten Sidoarjo merupakan DPC yang berada di dalam wilayah Gerbangkertasusila dengan proses kaderisasi terbaik. Karena dinilai terpelihara, tidak hanya secara formal namun juga secara informal (Jordan Batara, 
Wakil Sekretaris Internal DPD PDI Perjuangan Provinsi Jawa Timur, 10 Maret 2018).

Tidak ada bagian di dalam kehidupan yang dapat dipisahkan dari komunikasi, baik komunikasi secara langsung maupun tidak langsung, verbal maupun nonverbal. Komunikasi juga telah mengambil bagian yang cukup penting dalam organisasi dan kepemimpinan. Komunikasi yang terjadi secara terus-menerus di dalam sebuah organisasi akan membentuk sebuah pola. Pola komunikasi organisasi itu sendiri merupakan suatu sistem pengiriman pesan dari komunikator kepada komunikan dengan maksud untuk mengubah perilaku, sikap maupun pendapat.

Penelitian sebelumnya yang dilakukan oleh Priyowidodo dalam disertasinya (2013) dengan judul penelitian Politics and Organization in Opposition: Pattern of Communications and Decision Making in Parti Keadilan Rakyat (The People's Justice Party) of Malaysia menemukan bahwa Partai Keadilan Rakyat melakukan kedua pola komunikasi formal dan informal dengan baik. Damayanti (2018) dalam penelitiannya berjudul Pola Komunikasi Interpersonal dalam Pembentukan Kembali Konsep Diri, menemukan bahwa pola komunikasi yang terjadi adalah pola komunikasi lingkaran. Selain itu, Kartika \& Utaridah (2016) dalam penelitiannya berjudul Pola Komunikasi Etnografi Anak Jalanan di Bandar Lampung, menemukan bahwa mengemis dan bernyanyi dengan tidak memberikan andil dan membagikan kepada preman individu secara spesifik; mengemis dan bernyanyi secara sengaja atau tidak sengaja dengan menggunakan orang lain sebagai daya tarik; dan mengemis dan bernyanyi secara sengaja atau tidak sengaja dengan memanfaatkan kelemahan/cacat fisik. Perbedaan penelitian kali ini dengan yang sebelumnya adalah pola komunikasi organisasi dalam proses kaderisasi dan objek yang diteliti adalah organisasi partai politik. Penelitian sebelumnya sangat sulit ditemui pola komunikasi yang terjadi dalam organisasi partai politik khususnya dalam proses kaderisasi, sehingga penelitian ini nantinya diharapkan dapat mengisi kekosongan dan menambah perbendaharaan penelitian terkait pola komunikasi.

\section{TINJAUAN PUSTAKA}

\subsection{Komunikasi Organisasi}

Miller (2003, p.1) mengartikan komunikasi organisasi dapat dilakukan dalam berbagai cara, tapi ada kesepakatan bahwa organisasi melibatkan kolektivitas sosial (sekelompok orang) di mana semua aktivitasnya dikordinasikan untuk mencapai suatu tujuan, baik tujuan individu maupun tujuan kolektif. Dengan aktivitas yang terkoordinasi dalam beberapa tingkatan struktur organisasi diciptakan untuk membantu individu-individu bekerjasama satu sama lain dalam lingkungan organisasi yang lebih besar.

\subsection{Pola Komunikasi Organisasi}

Pola komunikasi organisasi merupakan sistem pengiriman pesan dari komunikator kepada komunikan dengan maksud untuk mengubah perilaku, sikap, maupun pendapat. Pola ini dapat dilihat dari bagaimana informasi disampaikan ke seluruh bagian organisasi dan bagaimana informasi diterima dari seluruh bagian organisasi. Menurut hasil penelitian Priyowidodo (2013, p. 115), teori pola komunikasi organisasi terbagi atas tiga pola sebagai berikut:

Pola Komunikasi Formal yang berkaitan dengan arah pesan (atas ke bawah, atau bawah ke atas), sumber dan penerima pesan (anggota khusus) dan isi pesannya (aspirasi atau instruksi) yang menjelaskan elemen tersebut. Menurut Ludlow \& Panton (2000, p. 29) saluran formal merupakan saluran yang telah ditetapkan oleh organisasi dan pesannya mengalir ke dalam tiga arah: ke bawah, ke atas dan ke samping. Fungsi utama komunikasi dari bawah ke atas menurut Stoner dan Freeman (1994, p.157), adalah untuk memberikan informasi kepada tingkat-tingkat yang lebih tinggi mengenai apa yang terjadi pada tingkat yang lebih rendah, contohnya meliputi laporan kemajuan, saran, penjelasan, permohonan bantuan atau keputusan. Sedangkan tujuan utama komunikasi dari atas ke bawah adalah untuk menasehati, memberitahukan, mengarahkan, memerintah dan menilai bawahan serta untuk memberi anggota organisasi informasi mengenai tujuan dan kebijakan organisasi. Contohnya antara lain berupa intruksi kerja, memo resmi, pengarahan kebijakan-kebijakan, prosedur, petunjuk, maupun peraturan, publikasi atau sosialisasi sarana organisasi, dan umpan balik kinerja pegawai. Pesan yang terkandung dalam komunikasi vertikal dijelaskan oleh Richmon dan Mc Croskey dalam bukunya yang berjudul "Organizational Communication for Survival" (2009, p. 29) ke dalam lima tipe, antara lain: a) Informasi bagaimana melakukan pekerjaan; b) Informasi mengenai dasar pemikiran untuk melakukan pekerjaan. c) Informasi mengenai kebijakan dan praktek-praktek organisasi. d) Informasi mengenai kinerja karyawan. e) Informasi untuk mengembangkan rasa memiliki tugas.

Pola komunikasi informal berkaitan dengan jenis pesan yang ada di dalam peristiwa. Priyowidodo (2013, p. 299), mengatakan di dalam hasil penelitiannya terdapat tiga jenis komunikasi informal, di 
antaranya: Cross Channel merupakan informasi yang diberikan melewati batas-batas unit kerja, dan di antara orang-orang yang satu dengan yang lainnya tidak menjadi bawahan maupun atasan. Davis dalam Pace \& Faules (2006, p. 197), menambahkan bahwa komunikasi lintas saluran, orang-orangnya tidak memiliki otoritas lini untuk mengarahkan orang-orang yang berkomunikasi dengannya dan terutama harus mempromosikan gagasan-gagasan mereka. Namun, mereka memiliki mobilitas tinggi dalam organisasi, mereka dapat mengunjungi bagian lain atau meninggalkan kantor mereka hanya untuk terlibat dalam komunikasi informal; Lateral adalah pesan yang disampaikan oleh orang-orang yang berada dalam posisi yang sama dan biasa terjadi dalam rapat komisi, interaksi pribadi, selama waktu istirahat obrolan di telpon, memo dan catatan. Komunikasi Horizontal/ Lateral menurut Pace \& Faules (2006, p. 195-196), paling sedikit memiliki enam tujuan berikut: a) Untuk mengkoordinasikan penugasan kerja, b) Berbagi informasi mengenai rencana dan kegiatan, c) Untuk memecahkan masalah, d) Untuk me mperoleh pemahaman bersama, e) Untuk mendamaikan, berunding, dan menengahi perbedaan, f) Untuk menumbuhkan dukungan antarpersona; Grapevine di sisi lain merupakan pesan yang berisi kejadian nyata namun susah untuk dibuktikan. Sifat-sifat selentingan digambarkan oleh Davis dan O'Connor dalam Face \& Faules (2006, p.196) sebagai berikut: a) Selentingan berjalan terutama melalui interaksi mulut ke mulut, b) Selentingan umumnya bebas dari kendalakendala organisasi dan posisi, c) Selentingan meyebarkan informasi dengan cepat, d) Jaringan kerja selentingan digambarkan sebagai suatu "rantai kelompok", e) Para pekerja dalam jaringan kerja selentingan cenderung menjalankan satu dari tiga peranan berikut: penghubung, penyendiri atau pengakhir. f) Lebih merupakan produk suatu situasi daripada produk orang-orang dalam organisasi tersebut, g) Semakin cepat seseorang mengetahui suatu peristiwa yang baru saja terjadi, semakin besar kemungkinan ia menceritakannya kepada orang lain, h) Semakin menarik perhatian, semakin besar kemungkinan informasi itu disampaikan kepada orang lain, i) Aliran utama informasi selentingan cenderung terjadi dalam kelompok-kelompok fungsional daripada antar kelompok-kelompok tersebut, j) Umumnya, $75 \%$ - 90\% dari rincian pesan yang disampaikan oleh selentingan cermat, k) Informasi selentingan biasanya tidak lengkap, menghasilkan kesalahan interpretasi bahkan bila rinciannya cermat, 1) Selentingan cenderung mempengaruhi organisasi. Menurut Ludlow dan Panton komunikasi informal terbentuk dari kesamaan kepentingan di antara orang- orang dalam organisasi. Saluran informal seringkali menjadi satu-satunya sarana komunikasi ketika saluran formal mengalami kemacetan atau gangguan (2000, p. 29).

Pola komunikasi socialization mechanism berkaitan dengan media yang digunakan oleh sebuah organisasi untuk mengantarkan pesan. Media tersebut bisa berupa media internal maupun eksternal (Priyowidodo, 2013, p. 300). Menurut Pace \& Faules dalam bukunya yang berjudul Komunikasi Organisasi Strategi Meningkatkan Kinerja Perusahaan (2006), mengatakan bahwa pemilihan media dapat didasarkan pada pertimbangan sifat-sifat media, hasil-hasil yang diinginkan, faktor biaya dan waktu, dan konteks budaya di tempat terjadinya pertukaran informasi tersebut (p. 189). Widjaya (2000, p. 35) mengatakan channel adalah saluran penyampaian pesan, biasa juga disebut dengan media. Saluran atau media komunikasi dapat dikategorikan dalam dua bagian, yaitu; Media Umum dan Media Massa. Widjaya juga menambahkan bahwa saluran komunikasi selalu menyampaikan pesan yang dapat diterima melalui panca indera atau menggunakan media. Pesan biasanya biasanya dapat berlangsung melalui dua saluran, yaitu saluran formal atau yang bersifat resmi dan saluran informal atau tidak resmi.

\subsection{Hambatan Komunikasi}

Wursanto (2005, p. 171) meringkas hambatan komunikasi terdiri dari tiga macam, yaitu: 1. Hambatan yang bersifat teknis adalah hambatan yang disebabkan oleh berbagai faktor, seperti: a) Kurangnya sarana dan prasarana yang diperlukan dalam proses komunikasi, b) Penguasaan teknik dan metode berkomunikasi yang tidak sesuai, c) Kondisi fisik yang tidak memungkinkan terjadinya proses komunikasi yang dibagi menjadi kondisi fisik manusia, kondisi fisik yang berhubungan dengan waktu atau situasi/ keadaan, dan kondisi peralatan; 2. Hambatan semantik merupakan hambatan yang disebabkan kesalahan dalam menafsirkan, kesalahan dalam memberikan pengertian terhadap bahasa (kata-kata, kalimat, kode-kode) yang dipergunakan dalam proses komunikasi; 3. Hambatan perilaku disebut juga hambatan kemanusiaan. Hambatan yang disebabkan berbagai bentuk sikap atau perilaku, baik dari komunikator maupun komunikan. Hambatan perilaku tampak dalam berbagai bentuk, seperti: a) Pandangan yang sifatnya apriori, b) Prasangka yang didasarkan pada emosi, c) Suasana otoriter, d) Ketidakmauan untuk berubah, e) Sifat yang egosentris. 


\subsection{Kaderisasi Partai Politik}

Budiarjo (2008, p. 160-161), mengatakan bahwa partai politik adalah suatu kelompok yang terorganisir yang anggota-anggotanya mempunyai orientasi, nilainilai dan cita-cita yang sama. Tujuan kelompok ini adalah memperoleh kekuasaan politik dan merebut kedudukan politik melalui cara yang konstitusional untuk melaksanakan programnya. Dalam definisinya menurut (Partanto dan Bahri, dalam Harahap, 2017). kaderisasi adalah orang yang dididik untuk melanjutkan tongkat estapet dari suatu partai atau organisasi. Dalam kata lain, kader diartikan sebagai orang yang diharapkan dapat memegang peranan penting dalam sebuah organisasi. Partai politik memiliki sistem kaderisasi yang khas dibandingkan dengan organisasi lainnya. Proses kaderisasi partai politik diwujudkan dalam bentuk pendidikan politik melalui suatu pembinaan terhadap seseorang yang bertujuan agar seseorang itu dapat memahami nilai-nilai yang terkandung dalam sistem politik yang ideal yang hendak dibangun.

\subsection{Fenomenologi}

Fenomenologi adalah studi tentang pengetahuan yang berasal dari kesadaran atau cara di mana orang-orang menjadi paham akan objek-objek dan peristiwaperistiwa dengan mengalaminya secara sadar. Studi ini melihat objek-objek dan kejadian-kejadian dari sudut pandang perceiver, individu yang mengalami hal-hal tersebut (Littlejohn, 2009, p. 354).

Menurut Creswell (2007, p. 58) "The basic purpose of phenomenology is to reduce individual experiences with a phenomenon to a description of the universal essence". Tujuan dasar dari fenomenologi adalah untuk mereduksi pengalaman pribadi atas suatu fenomena dan menjelaskannya menjadi pemahaman umum.

\section{METODE}

Metode yang digunakan di dalam penelitian ini adalah metode fenomenologi dengan tahapan (Creswell 2007, p. 157): 1) Buat dan atur file untuk data 2) Bacalah teks, buat catatan margin, buat kode awal. 3) Jelaskan pengalaman pribadi melalui epoche. 4) Jelaskan esensi dari fenomena tersebut. 5) Kembangkan pernyataan yang signifikan. 6) Kelompokkan pernyataan ke dalam unit makna. 7) Kembangkan deskripsi tekstur "apa yang terjadi". 8) Kembangkan deskripsi struktural "bagaimana" fenomena itu dialami. 9) Kembangkan esensi. 10) Sajikan narasi dari "esensi" dari pengalaman.
Unit analisis yang peneliti wakili adalah individu yang terlibat dalam kaderisasi di DPC PDI Perjuangan Kabupaten Sidoarjo. Peneliti mengaitkan kriteriakriteria tersebut dengan pemilihan informan di DPC PDI Perjuangan Kabupaten Sidoarjo yang kemudian terpilih menjadi narasumber dalam penelitian ini, antara lain: 1) Taufik Hidayat sebagai Sekretaris DPC PDI Perjuangan Kabupaten Sidoarjo. 2) Nadia Bafaqih sebagai Ketua Badan Pendidikan dan Pelatihan Cabang di DPC PDI Perjuangan Kabupaten Sidoarjo. 3) Munir sebagai kader DPC PDI Perjuangan Kabupaten Sidoarjo dan juga merupakan Bendahara di tingkat PAC Wonoayu.

\section{HASIL DAN PEMBAHASAN}

Setelah melakukan wawancara dengan ketiga informan yaitu, Taufik, Nadia dan Munir. Peneliti menemukan beberapa data yang sesuai dengan topik penelitian pola komunikasi organisasi PDI Perjuangan dalam proses kaderisasi di DPC Kabupaten Sidoarjo. Pola komunikasi organisasi terbagi ke dalam tiga pola yaitu pola komunikasi formal, pola komunikasi informal dan pola komunikasi socialization mechanism.

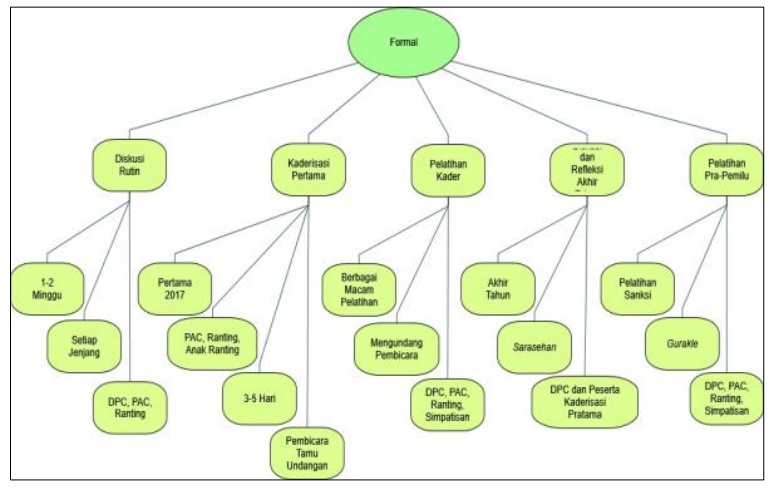

Gambar 1. Pola Komunikasi Organisasi Formal

\subsection{Pola Komunikasi Formal}

Setiap kegiatan yang termasuk dalam pola komunikasi formal memiliki pendekatan komunikasi organisasi yang berbeda dengan jenis pola yang lain. Berdasarkan bentuk pendekatan komunikasi organisasi yang dikatakan Miller (2013), dari beberapa jenis pendekatan, pola komunikasi formal dalam kaderisasi terlihat lebih menggunakan pendekatan klasikal. Hal ini dikarenakan apa yang didapatkan oleh para kader melalui setiap kegiatan sesuai dengan standart partai baik dari tingkat pusat maupun standart dari cabang, dan juga setiap kegiatan tersebut dirancang untuk menunjang peran mereka dalam organisasi. 
Para kader di DPC merupakan orang-orang yang diharapkan mampu membawa semangat partai ke tempat di mana mereka berada, serta diharapkan mampu mengkampanyekan PDI Perjuangan kepada orang lain, dan terlebih lagi para kader diharapkan mampu berdampak dan mempunyai peran di tengah masyarakat. Hal ini sesuai dengan definisi kaderisasi menurut Harahap dalam jurnalnya yang berjudul Kaderisasi dalam Partai Politik dan Pengaruhnya terhadap Kepemimpinan Nasional (2017).

\subsubsection{Kaderisasi Pratama}

Kaderisasi Pratama merupakan kegiatan yang dilaksanakan oleh DPC PDI Perjuangan Kabupaten Sidoarjo yang sebelumnya telah diatur dan dirancang oleh DPD. Kaderisasi Pratama merupakan hal yang wajib untuk dilaksanakan oleh setiap DPC kepada para kadernya, idealnya adalah setiap tahun sekali, namun dalam pelaksanaannya dikembalikan kepada setiap DPC untuk menentukan. Hal ini sesuai dengan pernyataan Ludlow \& Panton bahwa saluran formal merupakan saluran yang telah ditetapkan oleh organisasi (2000, p. 29).

Menurut hasil penelitian Priyowidodo, (2003) pola komunikasi formal berkaitan dengan arah pesan yaitu dari atas ke bawah atau bawah ke atas. Dalam hal ini kegiatan Kaderisasi Pratama, memiliki arah pesan dari atas ke bawah, yaitu pada tingkat DPC diperuntukkan bagi seluruh jenjang di bawah DPC, yaitu PAC, Ranting, Anak Ranting, maupun Simpatisan.

Sedangkan untuk sumber dan penerima pesannya juga merupakan anggota khusus yang telah dipersiapkan sebelumnya, hal ini sesuai dengan teori pola komunikasi organisasi formal menurut hasil penelitian Priyowidodo (2013) mengenai sumber dan penerima pesan adalah anggota khusus. Sebelumnya di tingkat DPC dibentuk suatu tim yang ditugaskan untuk mengatur segala sesuatu yang berkaitan dengan Kaderisasi Pratama, tim ini dinamakan Tim BADIKLAT-Cab. Tim BADIKLAT-Cab kemudian mengumpulkan peserta dari setiap jenjang, dan setiap jenjang mengirimkan utusan mereka masing-masing untuk mengikuti kegiatan ini.

Sumber pesan utamanya adalah dari DPC, yang disampaikan melalui mentor-mentor dari DPD dan DPP berpengalaman yang telah mereka tentukan, sedangkan pengurus DPC biasanya akan hadir sebagai mentor yang mendampingi setiap peserta. Sedangkan penerima pesannya adalah orang-orang khusus yang telah diutus sebelumnya dari jenjang di bawah DPC, yaitu PAC, Ranting, Anak Ranting dan Simpatisan. Sehingga arah pesan dominan dalam komunikasi pada kegiatan ini adalah dari atas ke bawah.

Komunikasi dari atas ke bawah sesuai dengan teori komunikasi formal menurut Stoner dan Freeman (1994, p. 157) mempunyai tujuan untuk menasehati, memberitahukan, mengarahkan, memerintah dan menilai bawahan serta untuk memberi anggota informasi mengenai tujuan dan kebijakan organisasi. Hal ini terjadi dalam Kaderisasi Pratama yang memiliki tujuan untuk menasehati melalui berbagai mentor maupun pembicara yang sudah lebih dulu terlibat dalam partai politik, untuk memberitahukan realitarealita yang terjadi di tengah masyarakat, untuk mengarahkan para kader bertindak sesuai dengan skills yang telah dilatihkan dan materi yang telah diberikan, dan untuk memerintahkan para kader bertindak dan mengambil peranan nyata di dalam masyarakat melalui pelatihan berbagai tugas lapangan.

Beberapa komunikasi dari bawah ke atas terjadi dalam bentuk diskusi dan dalam kelompok beserta dengan para mentor. Ketika dalam kelompok, ada studi kasus yang diberikan kepada para kader dan para kader diminta untuk menganalisis apa yang terjadi dan memberikan saran serta masukan yang berguna dalam studi kasus tersebut.

Pesan yang terkandung dalam kegiatan ini sesuai dengan lima tipe pesan komunikasi vertikal pernyataan dari Richmon dan Mc Croskey, yaitu; Informasi bagaimana melakukan pekerjaan; informasi mengenai dasar pemikiran untuk melakukan pekerjaan; informasi mengenai kebijakan dan praktekpraktek organisasi; informasi mengenai kinerja karyawan; informasi untuk mengembangkan rasa memiliki tugas (2009, p. 29). Kaderisasi Pratama memuat materi-materi yang membekali peserta dengan berbagai skills dan pemahaman bagaimana berorganisasi untuk mendukung peran masing-masing kader di dalam masyarakat. Para kader juga ditanamkan ideologi dasar partai yaitu Ideologi Pancasila sebagai pemikiran dasar yang dapat menyatukan para kader untuk bekerja bersama bagi Bangsa Indonesia. Informasi lain yang diberikan selama kegiatan Kaderisasi Pratama adalah berbagai kebijakan dan praktek-praktek organisasi seperti anggaran dasar, anggaran rumah tangga, maupun norma-norma partai lainnya kepada para kader. Para kader dilatih dengan berbagai ketrampilan yang dapat membentuk mental kader menjadi mental pejuang, hal ini ditanamkan 
agar setiap kader memiliki rasa juang yang tinggi serta tidak mudah menyerah untuk masyarakat dan terlebih juga untuk negara.

\subsubsection{Diskusi dan Refleksi Akhir Tahun}

Diskusi dan Refleksi Akhir Tahun merupakan sebuah kegiatan yang berawal dari ide yang dicetuskan oleh peserta kader untuk mengadakan perayaan akhir tahun bersama. Ide ini kemudian difasilitasi oleh DPC dengan membentuk sebuah kegiatan yaitu Diskusi dan Refleksi Akhir Tahun. Kegiatan ini mengambil konsep perayaan tahun baru namun dengan bentuk kegiatan yang lebih produktif dan mendidik, maka di dalamnya dimasukan ruang diskusi untuk mendiskusikan apa saja yang telah dilakukan peserta Kaderisasi Pratama pasca pelatihan.

Diskusi dan Refleksi Akhir Tahun ini diadakan oleh DPC dibantu oleh beberapa alumni Kaderisasi Pratama dengan mengundang seluruh peserta yang telah mengikuti Kaderisasi Pratama di DPC Kabupaten Sidoajo sebelumnya yaitu dari jenjang PAC, Ranting, Anak Ranting dan Simpatisan. Pihak dari DPC mendatangkan beberapa pembicara berpengalaman yang dinilai kompenten dan sesuai untuk memberikan materi kepada peserta di Diskusi dan Refleksi Akhri Tahun 2017 ini.

Kegiatan ini awalnya merupakan sebuah ide dari peserta kader, maka dapat dilihat komunikasi yang terjadi dari bawah ke atas berupa pemberian saran dan permohonan untuk mengadakan sebuah kegiatan, hal ini sesuai dengan pengertian komunikasi dari bawah ke atas menurut Stoner dan Freeman (1994) yang mengatakan komunikasi dari bawah ke atas adalah untuk memberikan informasi kepada tingkat-tingkat yang lebih tinggi contohnya saran.

Meskipun selanjutnya yang dominan terjadi dalam kegiatan ini adalah komunikasi yang terjadi dari atas ke bawah, sesuai dengan fungsi komunikasi yang diutarakan oleh Stoner dan Freeman (1994), yaitu untuk menilai dan menasehati para kader atas kinerja yang telah mereka lakukan pasca kaderisasi pratama, untuk memberitahukan melalui materi yang disampaikan oleh pembicara, untuk mengarahkan dan memerintahkan para kader bertindak sesuai dengan evaluasi yang telah diberikan dalam diskusi.

Pesan yang terkandung selama kegiatan yang telah disiapkan DPC kepada para kader berdasarkan teori Richmon dan Mc Croskey (2009) adalah mengenai informasi bagaimana para kader harus melakukan pekerjaan mereka bagi partai di tengah masyarakat berdasarkan hasil diskusi dan refleksi masing-masing, menegaskan ulang ideologi partai kepada para kader untuk menjadi bekal dan semangat melakukan pekerjaan, menginformasikan apa saja yang telah organisasi lakukan berkat pelaporan tugas akhir mereka, menginformasikan kineja para kader dan juga membangun semangat para kader untuk lebih giat bekerja dan menghasilkan sesuatu yang berdampak bagi masyarakat.

Berdasarkan analisis dari temuan data terkait kegiatan Diskusi dan Refleksi Akhir Tahun, maka kegiatan ini merupakan salah satu kegiatan yang termasuk ke dalam Pola Komunikasi Formal.

\subsubsection{Pelatihan Pra-Pemilu}

Pelatihan Pra-Pemilu merupakan kegiatan rutin yang dilaksanakan sebelum pemilihan umum. Orang-orang yang mengikuti pelatihan ini adalah para kader di setiap jenjang di bawah DPC yang dapat dibuktikan melalui kepemilikan KTA (kartu tanda anggota). Pemilihan umum merupakan suatu pesta demokrasi yang selalu diikuti oleh partai PDI Perjuangan, PDI Perjuangan khususnya DPC Kabupaten Sidoarjo mengirim utusannya untuk terlibat dalam pesta demokrasi baik sebagai saksi di TPS (tempat pemungutan suara), maupun sebagai Gurakle yaitu orang-orang yang menggerakan pemilih untuk mau menggunakan hak pilihnya. Hal ini sesuai dengan teori pola komunikasi organisasi formal menurut hasil penelitian Priyowidodo (2013), mengenai pola komunikasi formal yang berkaitan dengan arah pesan (atas ke bawah atau bawah ke atas), sumber dan penerimaan pesan (anggota khusus).

Orang-orang partai PDI Perjuangan yang terlibat sebagai saksi maupun Gurakle dibekali sebelumnya melalui pelatihan-pelatihan yang telah disiapkan oleh DPC Kabupaten. Komunikasi dominan yang terjadi dalam pelatihan ini adalah komunikasi dari atas ke bawah yaitu untuk memberitahukan mengapa saksi dan gurakle ini penting dan bagaimana peran mereka di dalam partai, untuk mengarahkan apa yang harus mereka lakukan sebagai saksi dan gurakle, untuk memerintahkan mereka melakukan sesuatu yang sesuai tugas dan tanggung jawab mereka. Hal ini sesuai dengan fungsi komunikasi atas ke bawah yang disampaikan oleh Stoner dan Freeman (1994, p. 157) yaitu untuk menasehati, memberitahukan, mengarahkan, memerintah, dan menilai bawahan, serta untuk memberi anggota organisasi informasi mengenai tujuan dan kebijakan organisasi. 
Pesan yang terkandung dalam pelatihan ini, sesuai dengan lima tipe pesan yang disampaikan dalam komunikasi vertikal oleh Richmon dan Mc Croskey (2009, p. 29), yaitu: informasi bagaimana melakukan pekerjaan; informasi mengenai dasar pemikiran untuk melakukan pekerjaan; informasi mengenai kebijakan dan praktek-praktek organisasi; informasi mengenai kinerja karyawan; informasi untuk mengembangkan rasa memiliki tugas. Dalam pelatihan ini adalah menginformasikan mereka bagaimana melakukan tugas mereka secara benar dan tepat sebagai saksi maupun gurakle, menginformasikan mengapa saksi dan gurakle ini penting sebagai dasar pemikiran mereka melaksanakan peran masing-masing, menginformasikan bagaimana kebijakan partai mengenai hal ini dan mendorong peserta untuk melaksanakan tugas ini berdasarkan semangat partai.

Berdasarkan analisis dari temuan data terkait kegiatan Pelatihan Pra-Pemilu, maka kegiatan ini merupakan salah satu kegiatan yang mengandung Pola Komunikasi Formal.

\subsubsection{Pelatihan Kader}

Pelatihan kader merupakan kegiatan yang diadakan untuk membekali peserta kader dengan berbagai macam ilmu dan ketrampilan yang dapat diterapkan dan digunakan oleh para. Hal ini juga dimaksudkan untuk mendukung peran mereka di tengah lingkungan masyarakat. Pelatihan kader merupakan sebuah bentuk kegiatan yang hampir sama dengan Kaderisasi Pratama berbentuk TOT (Training of Trainee), seminar, pembekalan, workshop yang dilaksanakan sesuai dengan kebutuhan partai.

Peserta pelatihan ini dapat diikuti oleh para kader yang berada di bawah jenjang DPC yaitu tingkat PAC, Ranting, Anak Ranting, dan Simpatisan. Setiap materi disampaikan oleh mentor yang telah dipersiapkan sebelumnya oleh pengurus DPC. Menurut hasil penelitian Priyowidodo (2013), pola komunikasi formal berkaitan dengan arah pesan (atas ke bawah, atau bawah ke atas), dan sumber dan penerima pesan (anggota khusus).

Komunikasi dominan yang terjadi dalam pelatihan ini adalah komunikasi dari atas ke bawah. Tujuan dari kegiatan ini adalah untuk memberitahukan kepada para kader seputar ilmu pengetahuan dan ketrampilan dalam berpolitik, mengarahkan para kader untuk menerapkan apa yang telah mereka dapatkan melalui setiap pelatihan dan memerintahkan para kader untuk melakukan sesuatu sesuai dengan pelatihan mereka yang dapat berdampak bagi masyarakat. Hal ini sesuai dengan tujuan utama komunikasi dari atas ke bawah yang disampaikan oleh Stoner dan Freeman (1994, p. 157) yaitu untuk menasehati, memberitahukan, mengarahkan, memerintah, dan menilai bawahan, serta untuk memberi anggota organisasi informasi mengenai tujuan dan kebijakan organisasi..

Pesan yang terkandung dalam kegiatan ini memuat lima tipe pesan yang terkandung dalam komunikasi vertikal oleh Richmon dan Mc Croskey, yaitu mengenai informasi bagaimana para kader melaksanakan tugas mereka setelah pelatihan diberikan, menanamkan kembali ideologi dasar partai yaitu Ideologi Pancasila agar dapat menjadi pedoman dan dasar pemikiran dalam melakukan pekerjaan, menginformasikan kebijakan-kebijakan partai dan mengapa partai melaksanakan pelatihan ini, serta menginformasikan kembali kepada para kader betapa pentingnya peran masing-masing kader di tengah masyarakat.

\subsubsection{Diskusi Rutin}

Diskusi Rutin merupakan sebuah kegiatan pertemuan yang dapat diikuti oleh siapa saja dalam jenjang kepengurusan termasuk para kader yang berada di bawah jenjang kepengurusan DPC yaitu PAC, Ranting, Anak Ranting. Peserta inti yang mengikuti diskusi ini tergantung dari topik bahasan yang dimuat dan dibahas selama diskusi. Jika diskusi diadakan di DPC, maka peserta yang hadir adalah seluruh pengurus DPC dan jenjang di bawah DPC. Jika diskusi diadakan di tingkat PAC, maka peserta yang hadir adalah DPC pendamping dan seluruh pengurus PAC dan jenjang di bawah PAC. Hal ini sesuai hasil penelitian Priyowidodo (2013), yang mengatakan arah pesan dari atas ke bawah atau bawah ke atas, sumber dan penerima pesannya merupakan anggota khusus.

Diskusi Rutin ini dilaksanakan setiap dua atau tiga minggu sekali tergantung dari seberapa banyak topik yang harus dibahas. Diskusi Rutin ini merupakan kewajiban partai dan beberapa pertemuan yang ada sudah dijadwalkan secara rutin untuk membahas berbagai perkembangan partai dan berbagai permasalahan yang dihadapi oleh partai.

Komunikasi yang terjadi dalam diskusi ini adalah dari atas ke bawah dan juga dari bawah ke atas. Komunikasi dari bawah ke atas berisi informasi mengenai apa yang terjadi pada jenjang masingmasing seperti tentang berbagai laporan kemajuan 
maupun permasalahan yang dihadapi di jenjang tersebut, berisi tentang saran atas permasalahan yang dibahas maupun untuk pengembangan partai, berisi tentang perjelasan atas apa yang menjadi topik bahasan dari pemahaman setiap peserta yang hadir. Sedangkan komunikasi dari atas ke bawah yang terjadi berisikan nasehat untuk mengatasi permasalahan yang ada, berisikan pemberitahuan tentang perkembangan dan permasalahan yang terjadi di dalam partai, mengarahkan dan memerintahkan peserta kader untuk terlibat langsung dalam suatu keputusan yang telah disepakati. Hal ini sesuai dengan fungsi utama komunikasi dari atas ke bawah yang disampaikan oleh Stoner dan Freeman (1994, p. 157) yaitu untuk menasehati, memberitahukan, mengarahkan, memerintah, dan menilai bawahan, serta untuk memberi anggota organisasi informasi mengenai tujuan dan kebijakan organisasi.

Isi pesan yang disampaikan dalam diskusi, memuat lima tipe pesan komunikasi vertikal oleh Richmon dan Mc Croskey, yaitu membahas masalah-masalah terkini di partai ataupun sekedar pertemuan rutin yang membahas usulan dan aspirasi pembangunan daerah. Hal ini termasuk menginformasikan bagaimana peserta kader melakukan sesuatu yang sesuai dengan peran mereka, membangun kembali semangat partai yaitu Ideologi Pancasila kepada seluruh peserta kader, menginformasikan kebijakan-kebijakan yang partai ambil dan bagaimana praktek tersebut dijalankan, dan memberikan beban kepada setiap kader untuk melaksanakan tugas mereka sesuai dengan peran masing-masing.

Berdasarkan temuan data di atas peneliti menemukan bahwa Diskusi Rutin mengandung Pola Komunikasi Formal.

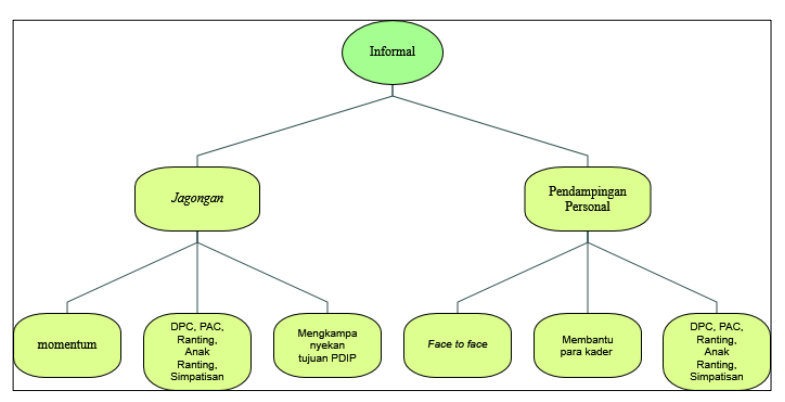

Gambar 2. Pola Komunikasi Informal

\subsection{Pola Komunikasi Informal}

Pola komunikasi informal menurut hasil penelitian Priyowidodo (2013), merupakan sebuah pola yang banyak berkaitan dengan jenis pesan di luar penger- tian Pola Komunikasi Formal. Terdapat beberapa jenis pesan yang termasuk ke dalam Pola Komunikasi Informal yaitu: 1) Cross Channel, pesan yang disampaikan oleh atasan kepada bawahan atapun sebaliknya. 2) Lateral adalah pesan yang disampaikan oleh orang-orang yang berada dalam posisi yang sama. 3) Grapevine di sisi lain berisi pesan yang berisi kejadian nyata namun susah untuk dibuktikan (selentingan).

Kegiatan-kegiatan yang peneliti kategorikan sebagai pola komunikasi informal, paling tidak memuat salah satu jenis pesan yang disampaikan oleh hasil penelitian Priyowidodo di atas.

Pola komunikasi informal yang terjadi di dalam DPC Kabupaten Sidoarjo dalam proses kaderisasi berdasarkan teori Miller (2003) dikaji melalui pendekatan Human Resources yang mengakui bahwa individuindividu dalam organisasi memiliki ide-ide ataupun masukan yang harus dipertimbangkan. Selain itu pendekatan ini mengakui bahwa individu tenaga kerja adalah unsur yang penting untuk memenuhi tujuan organisasi. Jadi, di dalam pendekatan ini ada penekanan pada kontribusi karyawan melalui pikiran dan ide-ide mereka. Pendekatan ini sesuai dengan pengakuan informan yang lebih menekankan kepada perbedaan setiap individu, baik dalam hal karakter maupun pola pikir. Hal ini lah yang membuat pengurus DPC melakukan pendekatan yang berbeda untuk orang yang berbeda. Semua ini dimaksudkan agar setiap kader dapat memberikan yang terbaik untuk memenuhi tujuan partai sesuai dengan peran mereka masing-masing.

\subsubsection{Jagongan}

Jagongan merupakan kegiatan yang dilaksanakan pada saat-saat tertentu saja dan bukan sebagai kewajiban yang harus dilaksanakan oleh partai. Kegiatan ini timbul dari adanya kebutuhan untuk saling mengetahui dan bertukar pendapat secara santai tanpa harus menunggu diadakannya rapat atau diskusi rutin. Ketika diadakannya Pemilihan Umum Gubernur dan Wakil Gubernur Jawa Timur 2018, Jagongan semakin giat dilaksanakan untuk mengobarkan semangat kampanye dan menyatukan pemikiran kader demi tujuan bersama partai.

Ketika jagongan dilaksanakan, tidak ada batasan posisi maupun tingkatan dan semua berhak untuk mengeluarkan suara. Peserta kader dan Pengurus DPC dipertemukan namun bukan lagi sebagai atasan dan bawahan, namun sebagai orang-orang yang 
memiliki kepentingan yang sama tanpa ada yang dikuasai dan yang menguasai.

Jagongan memiliki tujuan sesuai dengan teori Pace \& Faules (2006, p. 195-196) yaitu: untuk mengkoordinasikan penugasan kerja; berbagi informasi mengenai rencana dan kegiatan; untuk memecahkan masalah; untuk memperoleh pemahaman bersama; untuk mendamaikan, berunding, dan menengahi perbedaan, untuk menumbuhkan dukungan antarpersona. Jagongan dalam hal ini berbagi informasi mengenai rencana dan kegiatan yang akan dilaksanakan, berdiskusi untuk memecahkan masalah dan hambatan yang dialami partai, untuk menyamakan dan menyatukan pemahaman bersama tentang semangat kampanye untuk kemenangan partai, jika terdapat perbedaan atau perselisihan maka jagongan ini adalah waktu digunakan untuk memperdamaikan dan menengahi perbedaan, untuk menumbuhkan sikap saling mendukung satu sama lain agar terciptanya kesinambungan yang menguntungkan.

Jagongan juga merupakan kegiatan yang mengandung pesan-pesan selentingan (grapevine) yang disampaikan dari interaksi mulut ke mulut karena tidak begitu mengedepankan posisi dalam organisasi. Menurut hasil penelitian Priyowidodo (2013) yang mengenai jenis cross channel mengatakan informasi diberikan melewati batas-batas unit kerja dan di antara orang-orang yang satu dengan yang lainnya tidak menjadi bawahan maupun atasan.

\subsubsection{Pembinaan Personal}

Pembinaan personal merupakan kegiatan yang dilakukan di luar kepentingan partai dan dilakukan bebas secara waktu maupun lokasi. Komunikasi yang terjadi cenderung cross channel, menurut Davis dalam Pace \& Faules (2006), yaitu tanpa mengedepankan posisi dan jabatan namun sebagai pihak yang saling ingin membantu satu sama lain. Tim BADIKLAT$\mathrm{Cab}$ merupakan salah satu tim yang memiliki mobilisasi tinggi dalam organisasi dan mereka dapat mengunjungi setiap kader hanya untuk terlibat dalam komunikasi informal.

Hal-hal yang terkandung dalam pembinaan personal memiliki beberapa tujuan dari enam tujuan komunikasi lateral menurut Pace \& Faules (2006, p. 195196), yaitu bertujuan untuk: mengkoordinasikan penugasan kerja; berbagi informasi mengenai rencana dan kegiatan; untuk memecahkan masalah; untuk memperoleh pemahaman bersama; untuk mendamaikan, berunding, dan menengahi perbedaan; untuk menumbuhkan dukungan antar persona. Peserta kader secara tidak langsung akan diingatkan kembali mengenai tugas mereka masing-masing dan jika peserta kader mengalami kesulitan maka pengurus DPC yang terlibat dengan peserta kader tersebut akan memberikan dukungan maupun solusi atas permasalahan mereka.

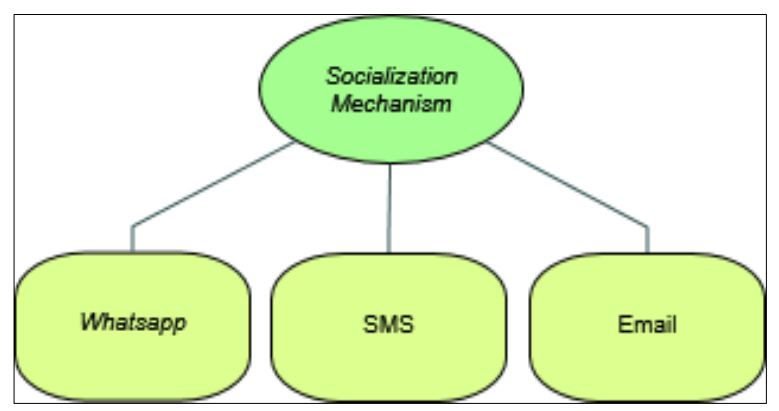

Gambar 3. Pola Komunikasi Socialization mechanism

\subsection{Pola Komunikasi Socialization Mechanism}

Pola komunikasi Socialization Mechanism berkaitan dengan media yang digunakan oleh sebuah organisasi untuk mengantarkan pesan. Media tersebut bisa berupa media internal maupun eksternal. Dalam hal ini media apa yang digunakan oleh DPC untuk mengantarkan pesan kepada peserta kader dalam proses kaderisasinya.

\subsubsection{WhatsApp (WA)}

WhatsApp merupakan media/medium yang membawa pesan setelah disandikan oleh sumber yaitu pengirim pesannya. Hal ini sesuai dengan teori O'Hair (2005, p. 22) yang mengatakan bahwa medium dapat didefiniskan sebagai media yang membawa pesan setelah disandikan langsung oleh sumber. WA merupakan media penyampaian pesan yang paling sering digunakan dalam proses kaderisasi. Hal ini dikarenakan, semua pengurus dan juga peserta kader sudah sebagian besar memiliki aplikasi Whatsapp pada handphone Androidnya.

Menurut Pace \& Faules (2006), pemilihan media ini sesuai dengan beberapa pertimbangan yaitu sifat-sifat media, hasil-hasil yang diinginkan, faktor biaya dan waktu, dan konteks budaya di tempat terjadinya pertukaran informasi. Penyebaran pesan melalui aplikasi Whatsapp juga dinilai cepat dan jarang mengalami hambatan sehingga hasil yang diinginkan oleh pengirim sama dengan hasil yang diterima oleh penerima pesan. Bahkan melalui aplikasi Whatsapp, pengirim dapat mengirimkan pesan bergerak dan 
bersuara seperti foto dan video. Selain itu Whatsapp juga memiliki berbagai fitur canggih yang dapat mempermudah pengiriman pesan. Biaya pengiriman pesan melalui aplikasi whatsapp ini juga murah karena hanya menggunakan kuota internet yang lebih murah daripada mencetak kertas ataupun biaya SMS. Ketika pesan dikirimkan oleh pengirim pesan, saat itu juga pesan akan diterima oleh penerima pesan jika kedua belah pihak sama-sama memiliki signal dan kuota yang memadai. Hal ini menunjukkan bahwa Whatsapp menjadi media penyampaian pesan yang mengandung pola komunikasi socialization mechanism yang digunakan DPC dalam proses kaderisasinya.

\subsection{Hambatan Komunikasi dalam Kaderisasi}

Hambatan komunikasi pengurus DPC dengan para kadernya dalam proses kaderisasi yang pertama adalah sulitnya mengkomunikasikan kepada para kader tentang seberapa besar peran masing-masing di tengah masyarakat, terutama kepada peserta kader yang berusia lanjut dan berada di tengah keadaan lingkungan yang sudah stabil. Berdasarkan teori yang disampaikan oleh Wusanto (2005, p. 171), hambatan yang bersifat teknis adalah hambatan yang disebabkan oleh berbagai faktor, seperti: Kurangnya sarana dan prasarana yang diperlukan dalam komunikasi; penguasaan teknik dan metode berkomunikasi yang tidak sesuai; kondisi fisik yang tidak memungkinkan terjadinya proses komunikasi yang dibagi menjadi kondisi fisik manusia, kondisi fisik yang berhubungan dengan waktu atau situasi/keadaan, dan kondisi peralatan. Hambatan ini jika dianalisis berdasarkan teori diatas merupakan hambatan yang bersifat teknik dikarenakan, kondisi fisik yaitu usia Pak Mul yang sudah tua, hal ini terlihat dari pernyataan Nadia yang mengatakan Pak Mul memiliki "fase di atas kita".

Hambatan eksternal lainnya yang dialami dalam melakukan komunikasi dengan peserta kader adalah keterbatasan peserta kader dalam hal penguasaan media sebagai alat penyampaian pesan. Hal ini juga termasuk dalam hambatan fisik yang disebabkan oleh penguasaan teknik dan metode berkomunikasi yang tidak sesuai. Hal ini sesuai dengan teori yang disampaikan oleh Wusanto (2005, p. 171), hambatan yang bersifat teknis adalah hambatan yang disebabkan oleh berbagai faktor, seperti: Kurangnya sarana dan prasarana yang diperlukan dalam komunikasi; penguasaan teknik dan metode berkomunikasi yang tidak sesuai; kondisi fisik yang tidak memungkinkan terjadinya proses komunikasi yang dibagi menjadi kondisi fisik manusia, kondisi fisik yang berhubungan dengan waktu atau situasi/keadaan, dan kondisi peralatan.

Hambatan eksternal selanjutnya yang ditemukan adalah jarak rentang usia di antara peserta kader. Hal ini membuat pengurus mengalami kesulitan dalam menentukan media komunikasi yang tepat dan juga materi yang tepat untuk peserta kader. Jika melihat teori yang disampaikan oleh Wusanto (2005, p. 171), hambatan yang bersifat teknis adalah hambatan yang disebabkan oleh berbagai faktor, seperti: Kurangnya sarana dan prasarana yang diperlukan dalam komunikasi; penguasaan teknik dan metode berkomunikasi yang tidak sesuai; kondisi fisik yang tidak memungkinkan terjadinya proses komunikasi yang dibagi menjadi kondisi fisik manusia, kondisi fisik yang berhubungan dengan waktu atau situasi/keadaan, dan kondisi peralatan. Hambatan ini termasuk ke dalam hambatan fisik karena kurangnya sarana dan prasarana yang diperlukan dalam proses komunikasi untuk mengatasi jarak rentang usia diantara para kader yang terlalu jauh.

Berdasarkan temuan dan analisis data yang peneliti temukan di lapangan peneliti menemukan keberhasilan kaderisasi melalui beberapa hal, yaitu; semangat diskusi, saling bertanya, dan studi banding.

\section{KESIMPULAN}

Penelitian ini dilakukan untuk melihat bagaimana pengalaman pola komunikasi organisasi PDI Perjuangan dalam proses kaderisasi di DPC Kabupaten Sidoarjo. Hasil dari penelitian ini ditemukan bahwa DPC PDI Perjuangan Kabupaten Sidoarjo dalam kaderisasinya melakukan tiga pola, yaitu pola komunikasi formal, pola komunikasi informal, dan pola socialization mechanism.

Pola komunikasi formal merupakan jenis pola yang memiliki variasi kegiatan paling banyak, DPC Kabupaten Sidoarjo mengirimkan pesan untuk menasehati, memberitahukan, mengarahkan, memerintah dan menilai bawahan serta untuk memberi anggota partai informasi mengenai tujuan dan kebijakan organisasi kepada para kader melalui setiap kegiatan yang dilaksanakan. Selain itu para kader juga akan memberikan informasi kepada jenjang yang lebih tinggi mengenai apa yang terjadi di jenjang bawah atau di lingkungan sekitar yang berpengaruh pada kerja partai.

Pola komunikasi informal adalah jenis pola yang banyak digunakan oleh DPC Kabupaten Sidoarjo 
untuk menjangkau dan menjawab peserta kader secara personal. Meskipun bentuk kegiatannya tidak terlalu bervariatif tapi pola ini digunakan secara intens oleh pengurus DPC dengan bukan lagi sebagai atasan dan bawahan dengan peserta kader, namun sebagai orang-orang yang memiliki kepentingan yang sama tanpa ada yang dikuasai dan yang menguasai.

Terakhir, adalah pola komunikasi socialization mechanism. Pola ini juga dilakukan oleh DPC Kabupaten Sidoarjo, meskipun dalam pelaksanannya tidak maksimal dikarenakan seperti tingkat penguasaan teknologi komunikasi yang tidak merata di daerah Kabupaten Sidoarjo. Media yang digunakan sebagai pertukaran informasi adalah media yang dinilai paling mampu menjadi perantara pesan diantara pengurus dan peserta kader.

Hambatan komunikasi dalam kaderisasi PDI Perjuangan yang sering terjadi adalah hambatan fisik. Hambatan fisik yang ada adalah kurangnya sarana dan prasarana yang diperlukan dalam komunikasi untuk mengatasi rentang usia yang begitu jauh diantara para kader; penguasaan teknik dan metode berkomunikasi yang tidak sesuai, sehingga beberapa kader tidak menguasai media yang digunakan; kondisi fisik manusia yang sudah berusia lanjut tidak memungkinkan untuk menerima informasi secara sempurna.

\section{DAFTAR PUSTAKA}

Budiardjo, M. (2008). Dasar-Dasar Ilmu Politik. Jakarta: PT. Gramedia Pustaka Utama.

Creswell, J. (2007). Qualitative Inquiry \& Research Design: Choosing Among Five Approaches, 2nd ed. California: Sage Publication

Mangkunegara, A. (2005). Perilaku dan Budaya Organisasi. Bandung: CV. Refika Aditama.

Mc Luhan, M. (2001) Understanding Media. London: Routledge.

Miller, K. (2003). Organization Communication: Approaches and Processes. Thomson, California.
O'Hair, D. (2005). Strategic Communication in Business and The Professions (5th edition). Boston, New York: Houghton Mifflin Company.

Oetomo, J. (2009). Bersyukur dan Menggugat Diri. Jakarta: Penerbit Kompas

Pace, R. \& Faules, D. (2006). Komunikasi Organisasi: Strategi Meningkatkan Kinerja Perusahaan. Bandung: PT. Remaja Rosdakarya.

Partanto, P. \& Dahlan, A. (1994). Kamus Ilmiah Populer. Surabaya: Rkola Surabaya.

Priyowidodo, G. (2013). Communication Patterns In Decision Making: Phenomenography Approach In Malaysia's And Indonesia's Political Organizations. (Ph.D. Thesis Unpublised). KedahMalaysia: Universiti Utara Malaysia.

Richmon, V.P. \& McCroskey, J. C. (2009). Organizational Communication for Survival. Boston: Allyn \& Bacon.

Stoner, J. A. F. \& Freeman. (1994). Manajemen (edisi Bahasa Indonesia). Edisi Kelima. Jakarta: Prenhallindo.

Stoner, J. A. F. \& Winkel, C. (2003). Perencanaan dan Pengambilan Keputusan dalam Manajemen. Jakarta: PT. Rineka Cipta.

Wursanto, I. (2005). Dasar-dasar Ilmu Organisasi. Yogyakarta: CV. Andi Offset.

Dhamayanti, I. 2018. Pola Komunikasi Interpersonal dalam Pembentukan Kembali Konsep Diri. Melalui website: https://eprints.uns.ac.id/39191/

Harahap, I.H. 2007. Kaderisasi Partai Politik dan Pengaruhnya Terhadap Kepemimpinan Nasional. Melalui website: http://repository.bakrie.ac. id/1246/1/01.\%20Kaderisasi\%20Parpol\%20dan $\% 20$ Pengaruhnya $\% 20$ thd $\% 20$ Kepemimpinan $\%$ 20Nasional\%20\%28Jurnal\%20Politik\%20LIPI $\% 29$.pdf

Kartika, T. \& Utaridah, N. 2016. The Pattern of Communication Ethnography of the Street Children in Bandar Lampung. Melalui website: https://ejournal.unisba.ac.id/index.php/mimbar/a rticle/view/1766/pdf. 